\title{
Announcement
}

\section{First WIPO Patent Information Fair}

The World Intellectual Property Organization (WIPO) is organizing the first worldwide Patent Information Fair to be held at the International Conference Centre of Geneva, 15 rue de Varembé, 1211 Geneva 20, Switzerland, on Wednesday, 26 September, and Thursday, 27 September, 1984.

Published patent documents constitute one of the largest sources of technological information in the world. Over thirty million separate patent documents have been published, and the number is growing at the rate of one million published patent documents each year. Patent documents are a vital source of technological information - since by definition they contain new information and ideas. Information is published in patent documents in a standardized manner, and generally before publication in journals. Patent documents are published on the presumption of universal access to anyone interested in their content.

The theme of the Fair is to be the online retrieval of patent information using computer data bases. The Fair will provide visitors with up-to-date information and guidance in searching through the treasure house of technological information contained in patent documents. The Fair will be of vital interest to research and development scientists, technical information specialists, as well as patent professionals.

The following producers and/or vendors of patent information have been invited to have stands at the Fair in order to demonstrate their services: Carl Heymanns Verlag, Chemical Abstracts Service, Derwent Publications Ltd., Engineering Information Inc., IFI/Plenum Data Company, Institution of Electrical Engineers (INSPEC), International Patent Documentation Center (INPADOC), Japan Patent Information Center (JAPATIC), Mead Data Central Corporation, Pergamon-InfoLine Ltd., Research Publications Ltd., and Télésystèmes-Questel S.A.

The industrial property offices of the following countries have been invited to demonstrate their patent information services: Australia, Austria, Brazil, Canada, Czechoslovakia, Denmark, Finland, France, German Democratic Republic, Federal Republic of Germany, Hungary, Japan, The Netherlands, Norway, Poland, the Soviet Union, Spain, Sweden, Switzerland, the United Kingdom, the United States of America. The European Patent Office has also been invited. 
Admission to the Fair will be free. It will be open from 10:00 a.m. to 5:00 p.m. on both days.

Further information can be obtained from WIPO, at 34 chemin des Colombettes, 1211 Geneva 20, Switzerland; tel. (022) 999-111, telex CH-22376, telegr. OMPI.

WIPO is an intergovernmental organization, and (since 1974) one of the fifteen specialized agencies of the United Nations system of organizations. Established in 1967, it is responsible for the promotion of the protection of intellectual property throughout the world through cooperation among the various states, and for the administration of various "unions", each founded on a multilateral treaty and dealing with the legal and administrative aspects of intellectual property. Intellectual property is taken to comprise two main branches: 1) industrial property, chiefly in inventions, trademarks, designs, and appellations of origin, and 2) copyright, chiefly in literary, musical, artistic, photographic and cinematographic works. WIPO encourages the conclusion of new international treaties and the harmonization of national legislations, it assembles and disseminates information, and it maintains services for international registration or other administrative cooperation among member states. A substantial part of the activities and the resources of WIPO is devoted to assistance to developing countries. Particular emphasis is laid on the transfer of technology, including know-how related to industrial property. The number of states belonging to WIPO, or party to treaties administered by WIPO, is well in excess of one hundred. 